Historia Slavorum Occidentis

2021, nr 4 (31)

ISSN 2084-1213

DOI: $10.15804 /$ hso210404

Staniseaw Boridczenko (Szczecin)

ORCID: 0000-0002-5343-5388

\title{
Obraz relacji polsko-rosyjskich w podręcznikach szkolnych Mojżesza Ostrogorskiego ${ }^{1}$
}

Keywords: Moisey Ostrogorsky, textbook narrative, Polish-Russian relations, Russian Empire, Poland

Słowa kluczowe: Mojżesz Ostrogorski, narracja podręcznikowa, relacje polsko-rosyjskie, Imperium Rosyjskie, Polska

Abstract: The goal of this article is to show how the history of Polish-Russian relations was presented in textbooks on the national history of the Russian Empire written by Moisey Ostrogorsky (1854-1921). To this end, a textual analysis was carried out.

\section{Wprowadzenie}

W drugiej połowie XIX w. w centrum zainteresowań historiografów cesarskorosyjskich znalazła się problematyka środkowoeuropejska. Przyczyniły się do tego rozwój terytorialny Imperium Rosyjskiego oraz snute przez inteligencję rosyjską wizje zjednoczenia wszystkich ludów słowiańskich pod berłem Romanowów. Nietrudno zgadnąć, iż помьский вопрос w ramach tych rozważań a priori był traktowany inaczej niż zagadnienia związane z relacjami państwa rosyjskiego z pozostałymi wspólnotami zamieszkującymi teren Europy Środkowej.

1 Artykuł został przygotowany dzięki wsparciu finansowemu Laboratorium Richarda E. Pipesa. 
Historia stosunków polsko-rosyjskich obfituje w liczne zatargi terytorialne, konflikty wojenne oraz rywalizację ideologiczną i religijną. Słowiańska bliskość kulturowa nie sprzyjała wzajemnemu zrozumieniu, lecz na odwrót, pogłębiała antagonizm. Od setek lat przy samookreśleniu przedstawiciele dwóch kultur podkreślali różnicę w kwestii przynależności religijnej, ustrojów państwowych, systemów wartości i norm zachowania ${ }^{2}$. Jak to zostało zauważone przez Piotra Głuszkowskiego wraz z Marią Leskinen, przeciwstawienie się „my - oni”, „nasz - obcy” w przypadku Rosjan i Polaków stało się czymś uniwersalnym i jawnym już pod koniec średniowiecza, co udowodnia m.in. korespondencja Andrieja Kurbskiego, listy Fiodora Karpowa i Filoteusza z Pskowa tudzież tzw. cykl kulikowy. Teksty polskie z tegoż okresu też świadczą o jawnym odróżnieniu mieszkańców państwa moskiewskiego - ciemnych niewolników cara - od nieustraszonego rycerza-Polaka ${ }^{3}$. Wraz z rozwojem historii jako nauki dawne stereotypy we wzajemnym postrzeganiu odcisnęły na niej swoje piętno. Narracja podręcznikowa wręcz stała się ich domeną.

Zadaniem niniejszego artykułu jest refleksja nad tym, w jaki sposób twórca jednego z najbardziej popularnych podręczników z przełomu XIX-XX w. dla szkół średnich Imperium Rosyjskiego - Mojżesz Ostrogorski ${ }^{4}$ - traktował problematykę relacji polsko-rosyjskich. W tym celu zamierzam przeanalizować ${ }^{5}$ teksty napisanych przez niego podręczników ${ }^{6}$ oraz innych materiałów do nauczania historii jego au-

2 Więcej na temat polskiej wyobraźni o sobie oraz o narodach ościennych, zob. A. Niewiara, Wyobrażenia o narodach $w$ pamiętnikach i dziennikach $z$ XVI-XIX wieku, Katowice 2000; taż, Ksztatty polskiej tożsamości. Potoczny dyskurs narodowy w perspektywie etnolingwistycznej (XVI-XX wiek), Katowice 2009.

3 P. Głuszkowski, M.A. Leskinen, Rosjanie i Polacy w XIX i na początku XX wieku: stereotypy we wzajemnym postrzeganiu, [w:] Polska - Rosja: XIX wiek. Materiały do nauczania historii, Lublin 2017, s. 328-329.

4 Biografia M. Ostrogorskiego została opisana w И.В. Анареев, М.Я. Острогорский. Жизнь и труды основоположника современной партологии, Moskwa 2017.

5 Analiza owa odbędzie się na podstawie zastosowania metodologii z pogranicza historii i nauki o komunikacji. Metodę podstawową stanowi DIMEAN, zob. I. Warnke, J. Spitzmüller, Wielopoziomowa lingwistyczna analiza dyskursu - DIMEAN, Tekst i Dyskurs = Text und Diskurs (2009), nr 2, s. 123-147.

6 М.Я. Острогорский, Учебник русской истории: элементарньй курс. С рисунками, картами, таблицами и вопросами для повторения. Аля средних учебных заведений и городских училищ, Петербург 1891; tenże, 1904; tenże 1910; tenże 1916; tenże, История России с картинками для народньх и других училищ, Петербург 1891; tenże, 1904; tenże 1910; tenże 1912. 
torstwa ${ }^{7}$. Analiza taka pozwoli wykryć sposób prezentacji relacji polsko-rosyjskich młodzieży szkolnej Imperium Rosyjskiego w oderwaniu od kwestii tegoż tematu w ramach dyskursu publicystycznego oraz akademickiego ${ }^{8}$, które pod koniec XIX i na początku XX w. wciąż pozostawały się obcymi dla większości mieszkańców imperium Romanowów. Innymi słowy skupić się wyłącznie na narracji Ostrogorskiego-podręcznikografa, pomijając pewne stereotypy i paradygmaty obowiązujące przy naświetleniu o wiele obszerniejszego tematu miejsca Polski i polskiej historii w historiografii i propagandzie Imperium Rosyjskiego drugiej połowy XIX-początku XX w. ${ }^{9}$ Dotychczas wątek ten w literaturze przedmiotu nie został opisany, choć bezspornie zasługuje na uwagę. Jako pomocniczy cel niniejszego artykułu wybrano wytypowanie aktorów, którzy według autorskiej wizji występowali jako główne podmioty toczącego się procesu historycznego. Osiągnięcie wymierzonych celów pozwoli utworzyć model, który ujawni nastawienie Ostrogorskiego do „obcych”, a szerzej, ujęcia w podręcznikach jego autorstwa kwestii wspólistnienia narodu imperialnego z narodem mu podwładnym.

Zaprezentowany temat wpisuje się w rozwinięty nurt studiów ostatniego dwudziestolecia nad imperiami w kontekście stosunków między „metropolią”/ „Centrum” a „koloniami”/ „peryferiami”. Wśród najwybitniejszych znawców tematu, których prace wywarły istotny wpływ na założenia poniższego artykułu, pragnę wymienić Henryka Głębockiego ${ }^{10}$, Leonida Gorizontowa ${ }^{11}$, Mariję Leskinen ${ }^{12}$,

7 Tenże, Хронология всеобщей и русской истории, Петербург 1873; tenże, Хронология русской истории, Петербург 1872.

8 Rozważanie na temat, jak mocno na rosyjskie myślenie wpływała „kwestia polska”, zostało opisane w A. Nowak, Metamorfozy Imperium Rosyjskiego 1721-1921. Geopolityka, ody i narody, Kraków 2018.

9 Na temat ten istnieje już pewna literatura przedmiotu: K. Blachowska, Narodziny imperium. Rozwój terytorialny państwa carów w ujęciu historyków rosyjskich XVIII i XIX wieku, Warszawa 2001; J. Maternicki, Dydaktyka historii w Polsce 1773-1918, Warszawa 1974; L. Szymański, Zarys polityki caratu wobec szkolnictwa ogólnokształcącego w Królestwie Polskim $w$ latach 1815-1915, Wrocław 1983.

10 Zob. H. Głębocki, Kresy Imperium: szkice i materiały do dziejów polityki Rosji wobec jej peryferii (XVIII-XXI wiek), Kraków 2006.

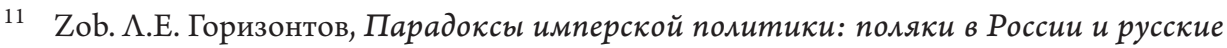
в Польше (ХІХ-начало ХХ в.), Москва 1999.

12 Zоb. М.В. Аескинен, Великоросс/великорус. Из истории конструирования этничности. Век XIX, Москва 2016; taż, Поляки и финны в российской науке второй половины XIX в.: «другой» сквозь призму идентичности, Москва 2010. 
Andrzeja Nowaka ${ }^{13}$, Wojciecha Materskiego ${ }^{14}$ oraz Alekseja Millera ${ }^{15}$. Jednocześnie pragnę podkreślić, że poniższy tekst $\mathrm{w}$ żadnym wypadku nie dąży do podania w wątpliwość paradygmatów o charakterze globalnym, lecz stanowi - jak się wydaje - konsekwentną próbę uzupełnienia wiedzy na podstawie studium pojedynczego przypadku. Artykuł składa się z dwóch części, które zostały wyodrębnione na podstawie rzeczowego podziału meritum: w części pierwszej na podstawie analizy ilościowej wytypowano i opisano najważniejsze wątki, w ramach których podręcznikograf poruszał zagadnienie relacji polsko-rosyjskich, w drugiej zaś - przedstawiono wyniki analizy jakościowej korpusu tekstów względem ich nastawienia do poruszonej problematyki.

\section{Narracja Mojżesza Ostrogorskiego w kontekście ujęcia historii relacji polsko-rosyjskich}

Dyskurs szkolny późnego Imperium Rosyjskiego bezspornie został zdominowany przez Dmitrija Iłowajskiego i serię jego podręczników ${ }^{16}$. Jednak bliżej początku XX w. dotychczas bezwzględnej dominacji narracji Iłowajskiego położył kres Mojżesz Ostrogorski wraz ze swymi publikacjami przeznaczonymi dla szkół podstawowych oraz średnich ${ }^{17}$. Owymi publikacjami były: Podręcznik historii rosyjskiej oraz Historia Rosji dla uczyliszcz narodowych. Po raz pierwszy ukazały się one w $1891 \mathrm{r}$. i szybko zyskały na popularności, o czym świadczy łączna liczba dodruków i kolejnych edycji, których w ciągu kolejnych trzydziestu lat było ponad siedemdziesią ${ }^{18}$.

13 Zob. A. Nowak, Metamorfozy; tenże, Ofiary, imperia i historycy. Studium przypadków (od XVIII do XXI wieku), Kraków 2009.

14 Zob. W. Materski, Od cara do „cara”. Studium rosyjskiej polityki historycznej, Warszawa 2017.

15 Zob. А. Мимер, Империя Романовых и национализм: эссе по методологии исторического исследования, Москва 2006.

16 В.И. Бабич, Иловайский Амитрий Иванович, [w:] Историки России. Биографии, Москва 2001, s. 260-262; В.Э. БагАасарян, Э.Н. Абдулаев, В.М. Клычников, А.Э. Аарионов, А.Ю Морозов, Школьный учебник истории и государственная политика: монография, Moskwa 2009, s. 202-205.

17 Н.А.Фукс, Школьные учебники по отечественной истории как историографический феномен (конец XVIII В. - вторая половина 1930-х годов), Москва 2010, s. 104.

18 Na podstawie przeprowadzonej kwerendy łączny nakład wszystkich edycji podręczników Ostrogorskiego został oszacowany na mieszczący się w przedziale 500-600 tys. egzemplarzy. Jak na warunki Imperium Rosyjskiego była to liczba imponująca. 
Przesłanki podobnego sukcesu prac Mojżesza Ostrogorskiego tkwią w tym, że już na samym początku powstawały one z myślą o przeznaczeniu komercyjnym (co dla Imperium Rosyjskiego stanowiło nowość $)^{19}$. Co ciekawe, zawartość podręczników była pewną niespodzianką dla inteligencji rosyjskiej. Stało się tak nie tylko dlatego, że wcześniej Mojżesz Ostrogorski mało interesował się historią jako nauką (dziś jest on znany przeważnie jako jeden z pierwszych politologów oraz socjologów politycznych z jedynie kilkoma publikacjami historycznymi na koncie), lecz także z powodu wiernopoddańczego sposobu ujęcia dziejów rosyjskich (choć Ostrogorski był znany ze swych antymonarchicznych i proliberalnych poglądów). Właśnie dlatego zawartość podręcznika jest niezwykle ciekawym przykładem unaocznienia dyskursu oficjalnego przez osobę przez dłuższy czas toczącą intelektualny spór ze zwolennikami absolutyzmu i triady Uwarowskiej ${ }^{20}$, co nie mogło nie pozostawić śladu na narracji podręcznikowej.

Z powodu dążenia do osadzenia poruszonej kwestii w nieco głębszym kontekście już przy przeprowadzeniu wstępnej analizy tekstów badanych została zastosowana ilościowa metoda badań. Na jej podstawie udało się ustalić, że informacje o stosunkach polsko-rosyjskich w publikacjach edukacyjnych Mojżesza Ostrogorskiego występują chronologicznie nierównomiernie ${ }^{21}$. Ponadto udało się wytypować pięć wątków, w ramach których najczęściej odwoływano do obrazu polskiego. Odbywa się to w ramach opisów: unii lubelskiej, wojny inflanckiej i Wielkiej Smuty, unii cerkiewnej, powstania Bogdana Chmielnickiego tudzież wojny kozackiej oraz rozbiorów Polski. Już sam spis tematów skłania do rozważań, gdyż unaocznia problematykę, która znalazła się w centrum autorskiej narracji o Polsce i Polakach, a wraz z tym o naturze ich relacji z Rosją i Rosjanami.

Tabela 1 uwzględnia wyniki analizy ilościowej korpusu tekstów względem wspomnień wybranych słowoform, bezpośrednio odwołujących do problematyki polskiej (za które zostały uznane wraz ze wszystkimi odmianami leksemy: Polak, Polska, polski).

\footnotetext{
19 Н.А.Фукс, Школьные учебники, s. 105.

20 Na temat triady w ramach dyskursu politycznego zob. np. Н.В. Асонов, «Теория офиииальной народности» в политическом дискурсе второй половины XIX-начала XX века, Социально-гуманитарные знания (2011) nr 2, s. 270-279; A. Miller, The Romanov Empire and Nationalism: Essays in the Methodology of Historical Research, Budapest-New York 2008, s. $140-159$.

21 W odróżnieniu, przykładowo, od wcześniej powstałych prac Iłowajskiego i podręcznika prof. Płatonowa.
} 
Tabela 1

\begin{tabular}{|l|c|c|}
\hline \multicolumn{1}{|c|}{ Słowo/słowoforma } & \multicolumn{2}{|c|}{ Uśredniona liczba (ogólna/na 100 str. tekstu) } \\
\hline & Podręcznik historii rosyjskiej & Historia Rosji \\
\hline Polak/Polacy & $42 / 24$ & $30 / 29$ \\
\hline Polska & $39 / 23$ & $12 / 12$ \\
\hline polski & $64 / 38$ & $31 / 30$ \\
\hline
\end{tabular}

Na skutek pobieżnej interpretacji wyników analizy ilościowej podręczników Mojżesza Ostrogorskiego może się wydawać, że obraz polski w jego pracach należy do rzadko występujących. Jednak należy zastrzec, że zawarte w jego tekstach wzmianki o stosunkach polsko-rosyjskich są skrajnie obszerne, obejmujące niekiedy całe podrozdziały. Podobna dychotomia (stosunkowo mała liczba wspomnień o Polsce i Polakach przy ich istotnym znaczeniu dla narracji) może być wyjaśniona zastosowanym przez autora sposobem ujęcia materiałów, polegającym na ich uproszczeniu przez zmniejszenie zawartości tekstowej i wypełnienie publikacji materiałami ilustracyjnymi. Porównanie liczby wzmianek o obrazie polskim z liczbą wzmianek o obrazach innych państw lub narodów (zawarte w tabeli 2) udowadnia powyższe twierdzenie.

Tabela 2

\begin{tabular}{|l|c|c|}
\hline \multicolumn{1}{|c|}{ Słowo/słowoforma } & \multicolumn{2}{c|}{ Uśredniona liczba (ogólna/na 100 str. tekstu) } \\
\hline & Podręcznik historii rosyjskiej & Historia Rosji \\
\hline Turcja/Turkowie/Ottomani & $23 / 13$ & $11 / 11$ \\
\hline Szwecja/Szwedzi & $31 / 18$ & $23 / 23$ \\
\hline Tatarzy & $105 / 61$ & $80 / 76$ \\
\hline Francja/Francuzi & $40 / 23$ & $28 / 27$ \\
\hline Polska/Polacy & $145 / 85$ & $73 / 71$ \\
\hline
\end{tabular}

Pierwsze wspomnienia o relacjach polsko-rosyjskich w podręcznikach Mojżesza Ostrogorskiego z reguly występują przy opisie wydarzeń z XIV w., w paragrafach poświęconych chrztowi Litwy ${ }^{22}$. Uznając Wielkie Księstwo Litewskie za alternatywne państwo ruskie ${ }^{23}$, autor skupia się na warunkach zawarcia unii pomiędzy nim a Polską. Z jednej strony, Ostrogorski przyznaje sukces unii w osiągnięciu nadrzędnego celu likwidacji zagrożenia niemieckiego. Z drugiej zaś, odwołuje do obrazu „okupanta polskiego", gdyż stwierdza, że na terenach rosyjskich, z których w znacznej

22 Zatytułowanych zazwyсzај Крещеніе Аитвы и соединеніе съ Польщею.
23 Stanowi to kontynuację wizji Rusi Zachodniej, zapoczątkowanej przez M. Ustriałowa. 
mierze składała się Litwa, doszło do poszerzenia wpływów polskich i katolickich ${ }^{24}$. Co warto zauważyć, Ostrogorski jako pierwszy podręcznikograf cesarskorosyjski dokonał względnie neutralnego i zbilansowanego przedstawienia transformacji państwa polsko-litewskiego ${ }^{25}$. Ukazał bowiem to państwo jako konfederację dwóch krajów połączonych wspólną dynastią. Co więcej, unia lubelska według niego stanowiła deklarację woli dwóch narodów (polskiego oraz zachodnioruskiego). Ten sposób wprowadzenia wątku polskiego do podręcznika może dziwić, gdyż z reguły przedstawienie relacji polsko-rosyjskich w literaturze cesarskorosyjskiej rozpoczynano od opisu potyczek Rusi Kijowskiej z Królestwem Polskim za czasów Bolesława Chrobrego $^{26}$. W ten sposób można stwierdzić, że w odróżnieniu od poprzedników ${ }^{27}$ Ostrogorski na początku publikacji nie kreował jednoznacznie negatywnego obrazu polskiego, lecz przeciwnie, uznawał państwo to za sojusznika w walce z Niemcami. Niemniej, już w tym wątku dochodziło do jasnego przeciwstawienia kultury i religii Polaków kulturze i religii Rusinów zamieszkujących Wielkie Księstwo Litewskie.

Po raz drugi na szeroką skalę do obrazu polskiego autor nawiązywał w ramach opisu konfliktu o ziemie zakonu inflanckiego. Wojnę tę autor wyjaśniał dążeniem Rosji do uzyskania dostępu do morza. Podkreślając potęgę państwa Iwana IV oraz to, że Zakon nie miał wystarczających sił, by podjąć z nim walkę, Ostrogorski omawiał decyzję „naczelnika” zakonu o złożeniu hołdu państwu polskiemu, co nie mogło nie obrócić Polaków w jedną ze stron toczącego się konfliktu. Choć pierwotnie, jak to ujmuje Ostrogorski, Polacy przegrywali tak samo jak i ich nowi poddani, jednak wraz z objęciem tronu polskiego przez Stefana Batorego - utalentowanego dowódcę posiadającego potężne wojsko składające się z Polaków i najemników węgierskich - sytuacja się odwróciła: przegrywać zaczęli Rosjanie ${ }^{28}$. Po wyczerpaniu sił obydwu stron, które nastąpiło dopiero po prawie dwudziestu pięciu latach skrajnie krwawej wojny, według Ostrogorskiego, doszło do podpisania traktatu pokojowego, na skutek którego Liwonia stała się częścią państwa polskiego, a Rosja została pozbawio-

\footnotetext{
24 М.Я. Острогорский, Учебник, s. 38-40.

25 Temat WKL w ujęciu historiografów cesarskorosyjskich został zaprezentowany w K. Błachowska, Wiele historii jednego państwa. Obraz dziejów Wielkiego Księstwa Litewskiego do 1569 r. w ujęciu historyków polskich, rosyjskich, ukraińskich, litewskich i białoruskich $w$ XIX w., Warszawa 2009.

26 Tradycja ta została zapoczątkowana przez Synopsis Kijowski.

27 Zaczynając od M. Ustriałowa (a szerzej - Jankowskiego) i kończąc I. Biellarminowym.

28 М.Я. Острогорский, Учебник, s. 65.
} 
na jakiegokolwiek dostępu do morza. Co warte uwagi, narracja opisująca konflikt o Inflanty wydaje się skrajnie neutralna w stosunku do Polski. Według autorskiego przekazu uczestnikiem konfliktu stała się ona w sposób całkowicie przypadkowy - wskutek poddania się pod władzę polską przegrywającego z Rosjanami mistrza zakonu. Co więcej, Ostrogorski nie szczędził pochwał Stefanowi Batoremu, którego uznawał za najwybitniejszego dowódcę i utalentowanego wojownika.

Znajdujący się w następnych rozdziałach opis Wielkiej Smuty kontynuuje już zaznaczony trend przeważnie neutralnego nastawienia do Polski jako państwa, z niekiedy negatywnymi wzmiankami o narodzie polskim. Wspominając o pojawieniu się na terenie polskim Dymitra Samozwańca, historyk zajmuje ciekawe stanowisko, stwierdzając, że ta osoba sama mogła wierzyć w fakt swej przynależności do domu Rurykowiczów. Opisując wydarzenia idące w ślad za pojawieniem się samozwańca, narracja skupia się na kwestii wsparcia okazanego Łżedymitrowi przez „panów i nawet samego króla polskiego" ${ }^{29}$. Przychylność polska względem pretendenta na tron moskiewski zostaje wytłumaczona chęcią wykorzystania okazji do wzmocnienia Polski kosztem Rosji. W sposób zwięzły autor wspomina o istnieniu pomiędzy Polską a Rosją terenów, o które spór już niejednokrotnie doprowadzał do wojen: „МежАу Россіею и Польшею Аавно уже шла вражАа за пограничныя области, и не разъ уже Аъмо Аоходимо Ао войны" ${ }^{30}$. Oddzielnie autor przedstawia interes duchowieństwa katolickiego w nawróceniu ludu prawosławnego na katolicyzm za pomocą samozwańca.

Wzmianki o Polsce, występujące w wątkach poświęconych rządom Dymitra I którego zresztą historyk uznaje za bardzo dobrego władcę, stawiającego na modernizację i demokratyzację Rosji - polegają na docelowej demonizacji obrazu polskiego. Opisując wstępne sukcesy Samozwańca w zdobyciu poparcia ludu, Ostrogorski zaznacza, że najbliższe otoczenie nowego cara, składające się z przybyłych razem z nim Polaków i Zachodniorusinów, swym zachowaniem przyczyniło się do znienawidzenia nowego władzy przez mieszkańców Moskwy. Polacy bowiem w sposób pogardliwy traktowali mieszkańców stolicy rosyjskiej; znęcali się nad nimi w sposób otwarty $^{31}$. Niezadowolenie to zostało wykorzystane przez najwyższą arystokrację rosyjską (bardzo niezadowoloną z reform Samozwańca) - wszczęła ona bunt i zabiła Dymitra I. Upadek tegoż władcy - oświeconego reformatora, który swymi czynami

\footnotetext{
29 Tenże, История, s. 51.

30 Tenże, Учебник, s. 72.

31 Tenże, Исторus, s. 52.
} 
prawie o wiek wyprzedził Piotra I - podręcznikograf w sposób jednoznaczny utożsamia z tym zaufaniem, którym obdarował on swe nikczemne i rusofobskie otoczenie.

Po śmierci Dymitra I, jak to ujmuje historyk, Polacy spróbowali wykorzystać zamęt wewnątrz państwa rosyjskiego w celu spustoszenia go i osłabienia. Dlatego okazali wsparcie kolejnym samozwańcom, przyczyniając się w ten sposób do niezmiernych cierpień ludu rosyjskiego. Jednak niedługo później doszło do kolejnych upokorzeń Rosji przez Polaków. Najwyższa arystokracja polska wraz ze swym królem zdecydowała się na podbicie ostatniej ostoi znienawidzonych przez nich Słowian Wschodnich, rozpoczynając inwazję przeciwko Rosji. W tym miejscu w omawianych tekstach po raz pierwszy sama Polska, a nie poszczególni awanturnicy polscy, występuje jako bezpośredni uczestnik Wielkiej Smuty. Co istotne, w swych podręcznikach Mojżesz Ostrogorski zwraca uwagę na istnienie licznego ugrupowania Rosjan gotowych do przyjęcia syna króla polskiego na tron rosyjski w celu zakończenia kryzysu państwa rosyjskiego. Opisując wydarzenia spowodowane zwycięstwem Polaków nad wojskami cara Wasyla I, autor wspomina o jego abdykacji i skomplikowanej sytuacji w Moskwie. W niej bowiem bojarzy zaczęli ad hoc składać przysięgę królewiczowi polskiemu, a w ślad za bojarami zaczęli robić to mieszczanie ${ }^{32}$. Teksty podręczników barwnie opisują, jak do obozu wojska polskiego oblegającego Smoleńsk została wysłana delegacja rosyjska, mająca na celu ustalenie warunków koronacji Władysława na cara Rosji. Jednak Zygmunt III zakazał synowi wyjazdu do Moskwy z powodu własnej chęci zdobycia tronu rosyjskiego: „Ho польскій король не хотьцъ отпустить сына, а желалъ самъ сАъцаться царемъ въ Россіи" ${ }^{33}$. Według narracji podręcznikowej stało się to momentem przełomowym, gdyż w ludzie rosyjskim przemówiło poczucie dumy narodowej: „ТогАа въ русскихъ мюАяхъ заговорило народное чувство, и они рђшили стать за родную страну противъ иноземцевъ” ${ }^{4}$. Jak podkreśla Mojżesz Ostrogorski, owa chęć została wsparta przez patriarchę rosyjskiego Hermogena, który uznał przysięgi wcześniej złożone królewiczowi Władysławowi za nieważne. W tym miejscu wydaje się logiczne podkreślenie rdzeni autorskiej narracji: nie odmawiał on Polakom ani odwagi, ani zdolności militarnych, jednak według niego miało to marne znaczenie, gdyż rozdmuchana pogarda panów polskich była ich głównym wrogiem, zdolnym do zniszczenia wszystkich ich osiągnięć.

\footnotetext{
32 Tamże, s. 53.

33 Tenże, Учебник, s. 75.

34 Tamże.
} 
W sposobie ujęcia przez Mojżesza Ostrogorskiego tematu opołczenia rosyjskiego pod dowództwem Minina i Pożarskiego dochodzi do ciekawego zjawiska: choć tekst porusza zagadnienie w sposób bezpośrednio związany z problematyką militarnego i politycznego konfliktu polsko-rosyjskiego, to jednak obraz wroga polskiego nie znajduje się w centrum jego narracji. Co więcej, autor w ogóle nie wspomina o Polsce, woląc używać o wiele mniej precyzyjnego określenia nоляки oraz nань. Przykładowo, opisując grono wojowników rosyjskich, autor nie odnosi się do kwestii tego, z kim powinni byli oni walczyć. Polacy i wojsko polskie, mające przyjść z odsieczą garnizonowi Kremla, zostają wspomniani dopiero przy opisie walk o Moskwę. Na zakończeniu tematu autor umiejscawia opis wybrania nowego cara z domu Romanowów oraz krótki tekst z wtedy już klasyczną legendą o bohaterskim czynie Iwana Susanina ${ }^{35}$.

Opisując rozpoczęcie rządów przez Michała Fiedorowicza, Ostrogorski w swych tekstach z reguly wspomina o zawarciu przez niego traktatu pokojowego z Polską. Jak zastrzega, miał on charakter wyjątkowo niekorzystny dla Rosji: „Скоро заключенъ былъ съ врагами (Помяками и Шведами) миръ, правда, на условіяхъ очень невыгодныхъ: пришлось уступить ньсколько старинныхъ русскихъ областей и уплатить большія Аеньги" ${ }^{36}$. Również w tym wątku podręcznikograf wytyka Polakom odpowiedzialność za śmierć poprzedniego patriarchy oraz uwięzienie na dłuższy czas ojca nowo wybranego cara. Początkuje to temat licznych pretensji wobec narodu polskiego, które ukierunkowują narrację występującą w kolejnych rozdziałach.

Wszystkie powyżej opisane tematy łączy to, że poruszają zagadnienie polskie w sposób neutralny raczej niż jednoznacznie negatywny. Kolejne wątki natomiast, poświęcone relacjom polsko-rosyjskim w XVII w., wymykają się z tego paradygmatu „obojętności”, gdyż prezentują zupełnie inne nastawienie do sposobu ich traktowania. W Podręczniku historii rosyjskiej podrozdział 43. został zatytułowany „Unia cerkiewna oraz polonizacja Rusi Zachodniej" ${ }^{37}$, natomiast w Historii Rosji dla uczyliszcz narodowych podrozdział 45. nosi tytuł „Unia i polonizacja Rosji Zachodniej”38. Jak wynika z samych tytułów, narracja w nich zawarta skupia się na problematyce wyznaniowo-kulturalnej XVII-XVIII-wiecznej Rzeczypospolitej. Opis owego zagadnienia autor umiejscawia w o wiele obszerniejszej polemice dotyczącej rozłamu

$35 \mathrm{O}$ znaczeniu mitu dla budowy tożsamości cesarskorosyjskiej zob. R. Wortman, Scenarios of Power: Myth and Ceremony in Russian Monarchy from Peter the Great to the Abdication of Nicholas II, Princeton-Oxford 2006, s. 243-282.

36 М.Я. Острогорский, Учебник, s. 79.

37 Tamże, s. 85.

38 Tenże, Исmopus, s. 60. 
wewnątrz Cerkwi prawosławnej i konfliktu między staroobrzędowcami a „nikonowcami”, łącząc dwa wątki: wewnątrzrosyjski oraz zachodnioruski i w ten sposób podkreślając jedność ludu rosyjskiego zamieszkującego Carstwo Rosyjskie oraz Rzeczpospolitą ${ }^{39}$. Właśnie w tych podrozdziałach po raz pierwszy autor w sposób jasny deklaruje, że ziemie ruskie trafiły pod władzę polską na skutek podboju i należy je

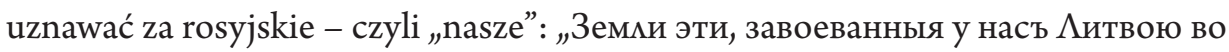
время татарщины, были присоединены къ польскому королевству посль сліянія

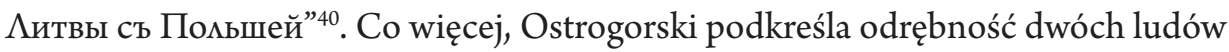
słowiańskich i ich wzajemną wrogość: „Поляки и Русскіе, хотя и были одного племени, не относились Аружелюбно Аругъ Къ Аругу. Они отличались и языкомъ и върой, ть были католики, а эти православные" ${ }^{41}$.

Opisując sytuację wyznaniową w Pierwszej Rzeczypospolitej, Mojżesz Ostrogorski konsekwentnie nagłaśnia fakt wykorzystania katolicyzmu (wraz z jego odmianą - unizmem) przez Polaków w celu pogłębienia swych wpływów na nowo przyłączonych ziemiach; uznaje go wręcz za narzędzie do prowadzenia polityki kolonialnej. Omawiając działania Polaków, mające na celu zakorzenienie unizmu wśród mieszkańców ziem ruskich, historyk aktywnie odnosi się do wprowadzonej przez niego do narracji podręcznikowej koncepcji „polonizacji” bądź опомячивания. Najważniejszą część owej wizji stanowi prezentacja hipotezy o odmiennym sposobie zachowania wobec wpływów polskich ludu i szlachty Rosji Zachodniej. Według Ostrogorskiego właśnie ludowi ruskiemu udało się zachować swe tradycje i tożsamość. Szlachta ruska natomiast poddała się „pokusie”, zdradzając swój język i wiarę na rzecz języka i wiary polskiej. Choć autor wszelako dąży do podkreślenia owej dychotomii społecznej, jednak stwierdza, że lud, przynajmniej częściowo, nie uniknął wpływów kultury polskiej, na skutek czego powstała „gwara małorosyjska”42 (język ukraiński) - innymi słowy „mieszkanka języka rosyjskiego ze słowami polskimi”.

Opis sytuacji religijnej w podręcznikach Ostrogorskiego stanowi swoisty wstęp do rozdziałów opisujących historię walki ludu ruskiego z ciemiężcami polskimi ${ }^{43}$.

39 Na temat odłamów narodu rosyjskiego i wykorzystania tegoż podziału w celach politycznych zob. T. Weeks, Nation and State in Late Imperial Russia: Nationalism and Russification on the Western Frontier 1863-1914, DeKalb 1996, s. 92-109.

40 М.Я. Острогорский, Учебник, s. 86.

41 Tamże, s. 77.

42 Tenże, История, s. 61.

43 Западно-русскіе крестьяне. Козачество ш М.Я. Острогорский, Учебник, s. 88; Козачество w tegoż, История, s. 62. 
W tych fragmentach tekstów dochodzi do uznania Polaków (jak również szlachty miejscowej, która poddała się polonizacji) za antagonistów prawosławia i Rosjan. Autor zaznacza wprowadzenie przez Polaków na ziemie ruskie polskiego typu pańszczyzny [крепостничества], czyli skrajnie antyludzkiej formy wykorzystywania chłopów do wykonywania obowiązków na rzecz właścicieli ziemskich, co pozostawało rzeczą obcą tradycji ruskiej, w ramach której był to typ relacji podobny do rodzinnego. Nie mając innego wyjścia, chłopi ruscy uciekali od panów-katów na ziemie pogranicza - na Ukrainę - gdzie nie znając polskiej niewoli, stworzyli nowy, dotychczas nieznany stan społeczny - wolnych Kozaków.

Pierwotnie Kozacy mogli cieszyć się pewnymi przywilejami wynikającymi z tego, że byli wykorzystywani przez Polaków w celu obrony południowych granic Rzeczypospolitej. Jednak w dłuższej perspektywie - według narracji podręcznikowej - nie mogło nie dojść do konfliktu, gdyż pany nie chcieli pogodzić się z utratą kontroli nad swymi byłymi „niewolnikami” i zaczęli ujarzmiać ich przez stopniowe ograniczenie ich wolności. Tak obrany kierunek polityki polskiej zmusił Kozaków do kolejnego przesiedlenia się, tym razem z Ukrainy do Siczy Zaporoskiej. Właśnie Sicz według podręcznikografa stała się ostatnią ostoją - i nadzieją - ludu ruskiego zamieszkującego państwo polskie. Kozacy zaporoscy nieraz bowiem okazywali wsparcie antypolskim powstaniom ludowym i często sami rozpoczynali bunty przeciwko pasożytom polskim. Jednak, jak to ujmuje autor, „Помяки жестоко подавмяли ихъ” ${ }^{4}$.

W tym miejscu należy podkreślić, że w obydwu podręcznikach tekst prezentujący powyżej zaznaczony temat zawiera bardzo niezrozumiały sposób ujęcia wydarzeń. Brakuje mu logiczności, gdyż autor często wspomina o wydarzeniach, o których nie wzmiankuje we wcześniejszych rozdziałach. W tym wypadku narracja podręcznikowa wygląda na nieudaną próbę przeniesienia opisu tych wydarzeń, znanego z literatury akademickiej i wielkich syntez dziejów rosyjskich. Potwierdza to z jednej strony nadmiernie skomplikowany dyskurs wątku, w sposób znaczący odróżniający się od reszty tekstów Ostrogorskiego, z drugiej zaś - pewne niespójności i brak ciągłości z tekstem go poprzedzającym.

Kwintesencję opisu konfliktu polsko-ruskiego na ziemiach Rzeczypospolitej stanowi temat powstania Bohdana Chmielnickiego. Chronologicznie Mojżesz Ostrogorski dzieli to wydarzenie na trzy etapy: bunt kozacki pod dowództwem hetmana w sojuszu z Tatarami krymskimi, powstanie ludowe skierowane przeciwko „panom polskim" i co może zdziwić, Żydom oraz poddanie się Ukrainy pod władzę cara

44 Tenże, Учебник, s. 90. 
rosyjskiego. Ów wątek w sposób skrajnie wyraźny ujawnia niezwykle istotną koncepcję, stanowiącą integralną część dyskursu Ostrogorskiego. Powstanie Chmielnickiego jest przedstawiane jako szczytowe wydarzenie toczącego się od wieków konfliktu między pospolitym ludem rosyjskim/ruskim a ciemiężcami polskimi. Polacy i ich sprzymierzeńcy - elity ruskie, które poddały się polonizacji - uznawani są za wrogów chłopstwa ruskiego, porównywanych do Żydów ${ }^{45}$. Właśnie masowe uczestnictwo chłopów w powstaniu uznaje się za przyczynę sukcesów w konflikcie z „panami”, który według narracji podręcznikowej skończył się skrajnie korzystnym dla Rosjan Zachodnich rozejmem. Niemniej, według Ostrogorskiego była to jedynie krótka przerwa w rozgrywającej się wojnie, gdyż pany nie mieli zamiaru pogodzić się z podobnym upokorzeniem.

Właśnie w owych niepewnych warunkach Bohdan Chmielnicki spełnił wielowiekowe marzenie ludu ruskiego: zaproponował poddanie się pod władzę cara rosyjskiego $^{46}$. W tym miejscu Mojżesz Ostrogorski stwierdza, że Ukraina nareszcie mogła odetchnąć z ulgą, gdyż połączyła się z Rosją, gotową do obrony jej praw i swobód. Opisując reakcję Polski, autor wykazuje niezmierne zdziwienie zachowaniem Polaków, a mianowicie brakiem zgody z ich strony na przyłączenie się Ukrainy do Rosji i rozpoczęciem przez nich wojny przeciwko Rosji. Choć wojna ta miała charakter wcale pomyślnej dla strony rosyjskiej, historyk z ubolewaniem stwierdza, że na skutek zaniedbań dyplomatycznych skończyła się ona podziałem Ukrainy na dwie części - zachodnią (pozostałą pod władzą Polską) i wschodnią razem z Kijowem (która stała się częścią Rosji). Oddzielnie Mojżesz Ostrogorski omawia przyłączenie do Rosji ziem, które za czasów Wielkiej Smuty zostały utracone: Siewierszczyzny i Czernihowszczyzny. Na tym podniosłym podsumowaniu w podręcznikach Ostrogorskiego kończy się opis relacji polsko-rosyjskich w XVII w. i zaczyna się opis spraw wewnątrzrosyjskich.

Ostatni, i niezwykle istotny z perspektywy obrazu relacji polsko-rosyjskich, wątek odwołujący się do „kwestii polskiej” stanowi zagadnienie rozbiorów Polski. W porównaniu do powyżej opisanego zarysu sytuacji narodowościowej i wyznaniowej w Pierwszej Rzeczypospolitej w XVII w. wydaje się on bardzo zwięzly ${ }^{47}$. Autor zaznacza, że nawet po utracie ziem małoruskich Polacy kontynuowali do-

\footnotetext{
45 Tenże, Исторus, s. 63.

46 Tenże, Учебник, s. 91.

$47 \mathrm{~W}$ obydwu podręcznikach mieści się on w krótkich paragrafach zatytułowanych „Upadek Polski” [Паденіе Польши]. М.Я. Острогорский, Учебник, s. 145; tenże, История, s. 100.
} 
tychczasową antyprawosławną politykę, wymierzoną w ruską mniejszość narodową. $\mathrm{Z}$ narracji tekstu wynika, że autor z reguły uznawal, że potencjonalny uczeń stanowi przedstawiciela tejże wspólnoty. Dlatego nie powinno dziwić, że w tekstach pojawia się smutny ton przy opisach podejmowanych przez Piotra I Wielkiego prób obrony praw jednowierców. Przez zawarcie umowy z władcą polskim próby te skończyły się niepowodzeniem ze względu na to, że król polski nie posiadał realnej władzy nad swymi poddanymi: „Всьмъ заправмяли паны, а они только заводили смуты, своевольничали и довели, наконецъ, государство до упадка"48.

Według autorskiej narracji sposób traktowania mniejszości religijnych w Polsce zmusił państwa ościenne do aktywnego zaangażowania się w jej sprawy wewnętrzne. Były to działania o naturze altruistycznej, uzasadnione zwykłym humanizmem. Rosja wręcz musiała wysłać swoje wojska do państwa polskiego, nie przewidując żadnych korzystnych celów, jedynie próbując ocalić część z polskich poddanych $\mathrm{z}$ rąk zwariowanych fanatyków katolickich. Jednak kiedy wojska rosyjskie znalazły się w Polsce - jak zaznacza autor - Prusy, Austria i Rosja zrozumiały, że moment ten stanowi najlepszą okazję do zajęcia spornych terenów przygranicznych. Na skutek rozbioru niewdzięcznej Polski Rosja dostała Białoruśt9 : „Помяки вынуждены были согласиться на то" ${ }^{" 0}$. Właśnie w ten sposób Ostrogorski opisuje pierwszy rozbiór Polski.

Drugi i trzeci rozbiór są opisywane jako skutek tego, że pierwsza próba wyleczenia chorego polskiego organizmu skończyła się niepowodzeniem. Polska wciąż pozostawała opanowana przez chaos i nieład. Innymi słowy odpowiedzialnością w kolejnych secesjach ziem polskich autor obarcza Polaków, a mianowicie ich niezdolność do zorganizowania się w zdrowy organizm państwowy oraz ich ignorancję. Po upływie dwudziestu lat mocarstwa ościenne zostały zmuszone do kolejnego rozbioru, na skutek którego Rosja otrzymała tereny Wołynia i Podola. Jednak ów akt wywołał „bezsensowny ogólnopolski bunt”, stłumiony przez wojska rosyjskie pod dowództwem Suworowa. Właśnie w tych warunkach doszło do trzeciego z rzędu rozbioru, na skutek którego Polska przestała istnieć jako państwo: „Польскаго государства не стало (въ 1795 г.), и съ того времени Помяки живутъ подъ чужой властью" ${ }^{51}$. Na tym Mojżesz Ostrogorski kończy swoje odniesienia do problematyki

\footnotetext{
48 Tenże, Учебник, s. 147.

49 Co istotne, w podręcznikach użyto leksemu Бrı^ıopycis.

50 М.Я. Острогорский, Учебник, s. 147.

51 Tamże.
} 
polskiej: Polska i Polacy więcej w tekstach jego autorstwa już nie występują; nawet przy omówieniu rządów Aleksandra II.

\section{Dyskurs Mojżesza Ostrogorskiego}

Za najważniejszy wniosek, który można wyciągnąć z dokonanej analizy podręczników Mojżesza Ostrogorskiego, należy uznać odmienny sposób traktowania obrazu polskiego w zależności od tego, w jakim kontekście zostaje on wspomniany. Ton neutralny występuje przeważnie w wątkach odwołujących do państwa polskiego (stosunków Królestwa Polskiego/Rzeczypospolitej z Rosją - Rosjanami/Rusinami). Natomiast opis negatywny obejmuje ujęcie wydarzeń związanych z relacjami między Polakami a Rosjanami/Rusinami jako dwoma oddzielnymi etnosami (w znaczeniu bliskim do współczesnego rozumienia słowa „naród”) i ludami (postrzeganych w kontekście konfliktu klasowego: szlachty z chłopstwem i mieszczaństwem).

Inny wart uwagi moment stanowi zignorowanie przez Ostrogorskiego wątków odwołujących do problematyki stosunków polsko-rosyjskich za czasów Rusi Kijowskiej. Omijając jakiekolwiek wzmianki o Polsce bądź narodzie polskim w czasach wczesnego średniowiecza, autor kreuje obraz Rusi/Rosji jako pierwszego i najstarszego, wręcz jedynego państwa słowiańskiego. Wpisuje się to w kierunek pansłowiańskiego dyskursu urzędowego z przełomu XIX i XX w..$^{52}$, po raz kolejny podkreślając staranność autora w naśladowaniu nieoficjalnych wytycznych caratu.

W podręcznikach Ostrogorskiego występuje skrajnie nietypowa dla XIX-wiecznych podręczników cesarskorosyjskich cecha narracyjna: wspomnienia o Polakach jako wspólnocie narodowej występują znacznie częściej niż o Polsce jako państwie. Z tego powodu większość odwołań do wątku polskiego odbywa się w kontekście relacji międzyetnicznych (polsko-rosyjskich/ruskich), problematykę stosunków bilateralnych między dwoma państwami słowiańskimi należy natomiast uznać za zdecydowanie drugorzędną i skrajnie rzadko występującą. Takie podejście autorskie mogło być uwarunkowane różnymi przyczynami. Po pierwsze, liberalnymi poglądami Mojżesza Ostrogorskiego: prawdopodobnie taka narracja była prostym odzwierciedleniem autorskiego punktu widzenia przyszłego demokratycznego ustroju Rosji ${ }^{53}$. Po drugie,

52 Choć z podobnym twierdzeniem nie wszyscy się zgadzają, zob. np. В.А. БолАин, Эволюиия панславистских политических концепиий в начале XX века (на примере журнала «Славянский век», 1900-1904), [Аиссертация], Москва 2018, s. 39-56.

53 R. Barker, X. Howard-Johnston, The Politics and Political Ideas of Moisei Ostrogorski, Political Studies 23 (1975), nr 4, s. 415-429. 
można przypuszczać, że zacieranie odniesień do państwowości polskiej miało przyczyny polityczne, a mianowicie stanowiło próbę podporządkowania się aktywnie przeprowadzanej przez carat walce z polskością ${ }^{54}$. Po trzecie, istnieje prawdopodobieństwo, że na sposób ujęcia problematyki wywarł wpływ cesarskorosyjski dyskurs akademicki, który wtedy został zdominowany przez narodowościowe koncepcje postrzegania procesu historycznego.

Wspominając o kwestii narodowej, nie można zignorować tego, że autor utożsamia przynależność wyznaniową z przynależnością etniczną, w ten sposób dokonując podziału na linii Polacy-katolicy-Rosjanie-prawosławni ${ }^{55}$. Jednak stanowi to jedynie czynnik kategoryzacyjny, pozwalający na zarysowanie linii podziału na dwa narody. Innymi słowy w tekstach Mojżesza Ostrogorskiego problematyka wyznaniowa odgrywa rolę drugorzędną.

Co ciekawe, teksty publikacji Ostrogorskiego jednoznacznie ignorują wojny polsko-rosyjskie ${ }^{56}$. Nie powinno więc dziwić, że Mojżesz Ostrogorski skrajnie rzadko odnosi się do kwestii rosyjskich pretensji terytorialnych do Polski. W tekstach jego autorstwa występują jedynie krótkie wzmianki o prawowitości rosyjskich roszczeń terytorialnych, odnoszące się do ziem utraconych za czasów Wielkiej Smuty. Jednocześnie należy zaznaczyć, że dla historyka samo pojęcie „terytorium” jest drugorzędne - o wiele większe znaczenie odgrywa lud terytorium ów zamieszkujący. Dlatego należy uznać, że Mojżesz Ostrogorski usprawiedliwiał roszczenia terytorialne w sposób dotychczas w cesarskorosyjskiej tradycji podręcznikowej niespotykany - przez uznanie prawa narodu (przeważnie rosyjskiego) do decydowania o własnej przynależności państwowej ${ }^{57}$.

Rekonstrukcja słów-stygmatów ujawniła, że stygmatyzacja i werbalna deprecjacja obrazu polskiego następuje na poziomie narodowym. Słowa-stygmaty (пан, шляхта, паразит, враг, оккупант) występujące w tekście są wymierzone przeciwko Polakom

54 Na ten temat zob. М. Аолбилов, Русский край; tenże, Полонофобия и политика русификации в северо-западном крае империи в 1860-х г2., [w:] Образ врага, Москва 2005, s. $127-133$.

55 Nie stanowi to zresztą wyjątku, odzwierciadlając wtedy już głęboko zakorzenioną tradycję historiografii, zob. М.В. Аескинен, Поляки и финны, s. 205-206.

$56 \mathrm{~W}$ tym kontekście warta polecenia wydaje się praca D. Lieven, Empire: The Russian Empire and Its Rivals, Yale 2002.

57 Co w tamtych czasach stanowiło nowość, zob. D. Staliūnas, Poland or Russia? Lithuania on the Russian Mental Map, [w:] Spatial Concepts of Lithuania in the Long Nineteenth Century, Boston 2019, s. 23-95. 
jako narodowi; ponadto potępiają one postawę polską wobec ludu rosyjskiego. W tekstach podręcznikowych dochodzi do częstego wykorzystania środków retorycznych ukierunkowanych na poniżenie Polski jako państwa i Polaków jako wspólnoty narodowej. Należy jednak zastrzec, że w większości wypadków mają one o wiele łagodniejszy charakter niż w innych podręcznikach powstałych w drugiej połowie XIX w. (np. podręcznikach Iłowajskiego, Ustriałowa, Biellarminowa itd.), zwłaszcza że negatywnie traktuje się en mass naród polski (utożsamiany przeważnie ze szlachtą), państwowość polską krytyka natomiast oszczędza. W książce autorstwa Mojżesza Ostrogorskiego zostały odnotowane przejawy sądów nominacyjnych i odgórnego orzeczenia. Wśród mechanizmów dyskryminacji obrazu polskiego można odnaleźć między innymi środki składniowe (przeważnie pasywizację obrazu polskiego), środki retoryczne i semantyczne (antroponimy, obelgi) oraz generalizacje. Zbadany korpus tekstów przypisuje narodowi (ale nie państwu) polskiemu pewne cechy, własności i atrybuty, które stanowią część mechanizmu dyskryminującego: niezdolność do zorganizowania się, okrucieństwo w stosunku do słabszych, fanatyzm religijny itd. ${ }^{58}$ Przy omówieniu historii nowożytnej natomiast wykorzystuje się dyskurs wykluczenia, a mianowicie przeciwstawienia ludu ruskiego „panom polskim”59.

\section{Podsumowanie}

Podręczniki Mojżesza Ostrogorskiego przedstawiają ciekawy sposób ujęcia problematyki relacji polsko-rosyjskich, gdyż brakuje im spójności nastawienia do opisu tychże relacji: niektóre z wątków prezentują stanowisko neutralne czy nawet propolskie, inne zaś ujawniają narrację antypolską. Na tamte czasy stanowiło to istotny ewenement, gdyż wypracowany w latach trzydziestych XIX w. przez Ustriałowa i de facto obowiązujący w ramach narracji podręcznikowej kanon ${ }^{60}$ polegał na

58 Ciekawe spojrzenie na rozwój semantycznego znaczenia leksemu „Polak” w cesarskorosyjskim dyskursie urzędowym prezentuje М. Аолбилов, Поляк в имперском политическом лексиконе, [w:] „Понятия о России”: К исторической семантике имперского периода, т. II, Москва 2012, s. 292-340.

59 Temat transformacji obrazu „panów polskich” w literaturze edukacyjnej Imperium Rosyjskiego został opisany w S. Boridczenko, Пан, значит враг? Семантический анализ слова пан в контексте описания исторического процесса учебниками Российской Империи по отечественной истории, Die Welt der Slaven: Internationale Halbjahresschrift für Slavistik 66 (2021), nr 1, 70-81.

60 Więcej na ten temat zob. K. Błachowska, Narodziny imperium. 
jednoznacznie negatywnym traktowaniu Polski i Polaków. Teksty Ostrogorskiego natomiast przywrócily do dyskursu szkolnego podejście do „kwestii polskiej” mniej jednoznaczne, znane z podręczników wykorzystywanych w ramach systemu oświaty przed powstaniem listopadowym ${ }^{61}$. Jednocześnie należy zaznaczyć, że choć Ostrogorski nie uznaje narodu polskiego za jednoznacznie odwiecznego wroga narodu rosyjskiego - za arcywroga - to jednak za pomocą środków stylistycznych stwarza nie najprzychylniejszy jego obraz, a mianowicie obraz „pana”: pasożyta, „ciemiężcy” ludu prawosławnego (rosyjskiego).

Jak udowodnił powyższy tekst, podstawą opisu relacji polsko-rosyjskich w analizowanych materiałach edukacyjnych była kwestia współistnienia dwóch narodów - ruskiego/rosyjskiego i polskiego; czasami również narodu polskiego i ludu ruskiego ${ }^{62}$, gdyż bardzo często przeciwstawiał on lud ruski szlachcie zachodnioruskiej, która według jego wizji „poddała się polonizacji” i została „wchłonięta przez naród polski”. Innymi słowy Mojżesz Ostrogorski zaproponował iście nowatorskie podejście do opisu dziejów Rosji - na pierwszy plan procesu historycznego wysunął on naród jako zbiorowy podmiot, w ten sposób całkowicie rezygnując z postrzegania historii jako całokształtu dziejów poszczególnych władców bądź podmiotów państwowych ${ }^{63}$. Powyżej zaznaczony fakt wydaje się odzwierciedleniem zmian zachodzących w imperium Romanowów. A mianowicie tego, że na skutek reform zapoczątkowanych przez Aleksandra II głównymi odbiorcami materiałów edukacyjnych wykorzystywanych w ramach systemu oświaty stali się przedstawiciele najniższych warstw społecznych, a nie jak dotychczas - szlachty i najbogatszego mieszczaństwa ${ }^{64}$. Przemiany nastąpiły również w dyskursie urzędowym; w ich wyniku za kręgosłup państwa rosyjskiego został uznany lud rosyjski ${ }^{65}$.

61 Zob. D. Staliūnas, Poland or Russia, s. 23-95.

62 O semantyce leksemu naród a lud w owym okresie zob. np. A. Мимер, История понятия нация в России, [w:] „Понятия о России”: К исторической семантике имперского периода, т. II, Moskwa 2012, s. 7-50.

63 Na temat podmiotowości narodu w podręcznikografii cesarkorosyjskiej zob. M.M. Przeciszewska, Naród, imperium, narracja. Podręczniki do historii Dymitra Iłowajskiego jako narzędzie rosyjskiej „polityki czytelniczej” w Królestwie Polskim, Slavia Orientalis LXIV (2015), nr 1, 42-43.

64 Т.А. Володина, Учебная митература по отечественной истории как предмет историографии: Середина XVIII-конец XIX вв. [Монография], Москва 2004.

65 А. Мимер, Империя Романовых, s. 147-171. 


\section{Bibliografia}

Barker R., Howard-Johnston X., The Politics and Political Ideas of Moisei Ostrogorski, Political Studies 23 (1975), nr 4.

Błachowska K., Narodziny imperium. Rozwój terytorialny państwa carów w ujęciu historyków rosyjskich XVIII i XIX wieku, Warszawa 2001.

Błachowska K., Wiele historii jednego państwa. Obraz dziejów Wielkiego Księstwa Litewskiego do 1569 r.w ujęciu historyków polskich, rosyjskich, ukraińskich, litewskich $i$ białoruskich $w$ XIX w., Warszawa 2009.

Boridczenko S., Пан, значит враг? Семантический анализ слова пан в контексте описания исторического процесса учебниками Российской Империи по отечественной истории, Die Welt der Slaven: Internationale Halbjahresschrift für Slavistik 66 (2021), nr 1.

Głębocki H., Kresy Imperium: szkice i materiały do dziejów polityki Rosji wobec jej peryferii (XVIII-XXI wiek), Kraków 2006.

Głuszkowski P., Leskinen M.A., Rosjanie i Polacy w XIX i na początku XX wieku: stereotypy we wzajemnym postrzeganiu, [w:] Polska - Rosja: XIX wiek. Materiaty do nauczania historii, Lublin 2017.

Lieven D., Empire: The Russian Empire and Its Rivals, Yale 2002.

Maternicki J., Dydaktyka historii w Polsce 1773-1918, Warszawa 1974.

Materski W., Od cara do „cara”. Studium rosyjskiej polityki historycznej, Warszawa 2017. Miller A., The Romanov Empire and Nationalism: Essays in the Methodology of Historical Research, Budapest-New York 2008.

Niewiara A., Ksztalty polskiej tożsamości. Potoczny dyskurs narodowy w perspektywie etnolingwistycznej (XVI-XX wiek), Katowice 2009.

Niewiara A., Wyobrażenia o narodach w pamiętnikach i dziennikach z XVI-XIX wieku, Katowice 2000.

Nowak A., Metamorfozy Imperium Rosyjskiego 1721-1921. Geopolityka, ody i narody, Kraków 2018.

Nowak A., Ofiary, imperia i historycy. Studium przypadków (od XVIII do XXI wieku), Kraków 2009.

Przeciszewska M.M., Naród, imperium, narracja. Podręczniki do historii Dymitra Itowajskiego jako narzędzie rosyjskiej „polityki czytelniczej” w Królestwie Polskim, Slavia Orientalis LXIV (2015), nr 1.

Staliūnas D., Poland or Russia? Lithuania on the Russian Mental Map, [w: ] Spatial Concepts of Lithuania in the Long Nineteenth Century, ed. by D. Staliūnas, Boston 2019. 
Szymański L., Zarys polityki caratu wobec szkolnictwa ogólnokształcącego w Królestwie Polskim w latach 1815-1915, Wrocław 1983.

Warnke I., Spitzmüller J., Wielopoziomowa lingwistyczna analiza dyskursu - DIMEAN, Tekst i Dyskurs = Text und Diskurs (2009), nr 2.

Weeks T., Nation and State in Late Imperial Russia: Nationalism and Russification on the Western Frontier 1863-1914, DeKalb 1996.

Wortman R., Scenarios of Power: Myth and Ceremony in Russian Monarchy from Peter the Great to the Abdication of Nicholas II, Princeton-Oxford 2006.

Андреев И.В., М.Я. Острогорский. Жизнь и труды основоположника современной партологии, Москва 2017.

Асонов Н.В., «Теория официальной народности» в политическом дискурсе второй половины XIX-начала XX века, Социально-гуманитарные знания (2011), nr 2. Бабич В.И., Иловайский Амитрий Иванович, [w: ] Историки России. Биографии, Москва 2001.

Багдасарян В.Э., АбАулаев Э.Н., КАычников В.М., Аарионов А.Э., Морозов А.Ю., Школьный учебник истории и государственная политика: монография, Москва 2009.

Болдин В.А., Эволюиия панславистских политических кониепиий в начале XX века (на примере журнала «Славянский век», 1900-1904) [Аиссертация], Москва 2018.

Володина Т.А., Учебная митература по отечественной истории как предмет историографии: Середина XVIII-конеи XIX вв. [Монография], Москва 2004.

Горизонтов $\Lambda$.Е., Парадоксы имперской политики: поляки в России и русские в Польше (ХІХ-начало XX в.), Москва 1999.

Аолбилов М., Полонофобия и политика русификаиии в северо-западном крае империи в 1860-х г2. w.: Образ врага, Москва 2005.

Аолбилов М., Поляк в имперском политическом лексиконе, [w: ]Понятия о России": К исторической семантике имперского периода, т. II, Moskwa 2012.

Аолбилов М., Русский край, чужая вера: Этноконфессиональная политика империи в Аитве и Белоруссии при Александре II, Москва 2010.

Иескинен М.В., Великоросс/великорус. Из истории конструирования этничности. Век ХІХ, Москва 2016.

Аескинен М.В., Поляки и финны в российской науке второй половины ХІХ в.: «другой» сквозь призму идентичности, Москва 2010.

Мияер А., Империя Романовых и национализм: эссе по методологии исторического исследования, Москва 2006. 
Миялер А., История понятия нация в России, [w: "Понятия о России”: К исторической семантике имперского периода, т. II, Москва 2012.

Острогорский М.Я., История России с картинками для народных и других учимищ, Петербург 1891.

Острогорский М.Я., Учебник русской истории: элементарный курс. С рисунками, картами, таблицами и вопросами для повторения. Аля средних учебных заведений и городских училищ,, Петербург 1891.

Острогорский М.Я., Хронология всеобщей и русской истории, Петербург 1873. Острогорский М.Я., Хронология русской истории, Петербург 1872.

Фукс Н.А., Школьные учебники по отечественной истории как историографический феномен (конеи XVIII в.-вторал половина 1930-х годов), Москва 2010.

\section{Summary}

\section{The portrayal of Polish-Russian relations in the Moisey Ostrogorsky's} textbooks

In 1891, in St. Petersburg two textbooks on Russian history were published; their author was Moisey Yakovlevich Ostrogorsky, a well-known liberal and anti-monarchist. Unbeknown to the public, the books marked the end of a long period of absolute prevalence of Dmitry Ilovaisky's discourse in the textbook narrative in the Russian Empire. Ostrogorsky's textbooks were read in various types of secondary schools throughout the Empire until 1917. In total, they had more than 70 editions and a total circulation of more than 500,000 copies.

Translated by Ewa Dratwa

Nadesłany: 12 I 2021

Nadesłany po poprawkach: 7 IX 2021

Zaakceptowany: 27 IX 2021

Mgr Stanisław Boridczenko

Uniwersytet Szczeciński

Wydział Humanistyczny

ul. Szwoleżerów 18/408

71-062 Szczecin

e-mail: boridczenko@gmail.com 